\title{
Features of Remote Work in Ukraine and the European Union: Comparative Legal Aspect
}

\author{
Oleg M. Yaroshenko ${ }^{1}$, Nataliia O. Melnychuk ${ }^{2}$, Sergiy V. Moroz ${ }^{3}$, Olena O. Havrylova ${ }^{4}$, \\ Yelyzaveta P. Yaryhina ${ }^{5}$ \\ ${ }^{1}$ Department of Labor Law, Yaroslav Mudryi National Law University, Ukraine. E-mail: \\ yaroshenko8171@neu.com.de \\ 2 Departament of Labor Law and Social Security Law, Institute of Law, Taras Shevchenko National University of \\ Kyiv, Ukraine. E-mail: melnychuk8171@acu-edu.cc \\ ${ }^{3}$ Department of State and Legal Disciplines, V. N. Karazin Kharkiv National University, Ukraine. E-mail: \\ moroz8171@edu-knu.com \\ ${ }^{4}$ Center for European Social Law Implementation Issues, Taras Shevchenko National University of Kyiv, Ukraine. \\ E-mail: havrylova8171@sci-univ.com \\ ${ }^{5}$ Department of Labor Law, Yaroslav Mudryi National Law University, Ukraine.E-mail: yaryhina8171@edu.cn.ua
}

\begin{abstract}
The relevance of the study is based on the development of scientific and technological progress and the expansion of the labor market, including in the framework of international cooperation. Moreover, the introduction of quarantine due to the spread of Covid-19 has led to increased attention to remote work. The aim of the study is to analyze the legal aspects of remote work in accordance with the labor legislation of Ukraine and the European Union, focusing on the concept of remote work, the rights and obligations of remote workers. In our study, we determined that in the European Union, the key points in relation to the rights granted to teleworkers, which the countries parties to the agreement have undertaken to incorporate into their national legislation and collective agreements, are data protection; the voluntary nature of telecommuting; equipment; organization of working time; privacy. The originality of the study is based on more effective ways to improve labor productivity in Ukraine, labor discipline, compliance with labor guarantees for remote work. It is necessary to revise and legislatively regulate the key principles of compliance by employees with labor discipline, providing the employee with proper working conditions, supporting the employer in search of new opportunities to provide employees with work, improving the technical aspects of ensuring the relationship between business and government, responsibility for results and the labor process.
\end{abstract}

Keywords: Covid-19; Labor Legislation; Labor Rights; Labor Relations; Remote Work; Telework

\section{Introduction}

The economy globalization processes in conjunction with the rapid development of the latest information and telecommunication technologies in society have led to radical changes called an information revolution. The labor system cannot ignore the relevant changes and should adequately respond to challenges of the information era. ${ }^{1}$ In addition, the development of the world in the XXI century is characterized by the active

\footnotetext{
1 M. Dei, and H. Dei, "Labor security in conditions of digital globalization." Fundamental and Applied Researches in Practice of Leading Scientific Schools, 26 no. 2 (2018): 299-304.
} 
introduction into various spheres of life of digital technologies, electronic networks, which is an important factor in the existence of post-industrial society. This led to the emergence of new opportunities for the realization of human rights in the field of social and labor relations. In essence, the preconditions are created for the virtualization of the economic space, combined with the real social interaction of the participants of social and legal relations. ${ }^{2}$ At the same time, a feature of the modern labor market is the significant spread of all types of telework. ${ }^{3}$

The ILO 4 estimates in its April 2020 report that about 260 million people (approximately $7.9 \%$ of the total workforce) worked remotely before the pandemic. It is likely that such a high rate is due to greater flexibility of employees. The same conclusions are set out in the report of the International Bar Association, published in September 2019: "Telework has proved to be a flexible way of working and allows employees to use virtual networks, shared platforms to work at home or outside the employer's office". ${ }^{5}$ Telework as a relatively new work arrangement offers employees freedom in terms of time and place of performance. It is an inherent feature of telework that employees are more autonomous in managing their own work without direct supervision. ${ }^{6}$ It should be noted that teleworking has a range of positive and negative consequences for employees, employers and wider society. ${ }^{7}$ Inter alia, telework increases the availability of work for many categories of the population (pensioners, the disabled, pregnant women, etc.), eliminates geographical difficulties (due to the Internet and other means of communication), social tensions.

Moreover, the employee can personally shape their work schedule, perform a job function in convenient conditions, which has a positive effect on their productivity and efficiency. As for the employer, their benefit is to minimize the cost of staff, rent office space, pay for utilities, purchase the necessary equipment, etc. ${ }^{8}$ Many organizations are realizing the benefits of telecommuting. Skilled workers who are competent enough to work with information and communication technologies, who are able to work and collaborate in a virtual environment, is an investment. It, in turn, can be assessed in the form of a motivated, loyal, as well as a long-term cheaper employee who does not require

2 Serhii Silchenko and Diana Serbina. "Remote working: current state and prospects of legal regulation." Entrepreneurship, Economy and Law, no. 1 (2021), 93-99. doi: 10.32849/26635313/2021.1.16.

3 B. Andrushkiv, "Distance work and freelance activity: features and differences." Scientific Information Bulletin 11, (2015), 233-237.

4 "Working from home: Estimating the worldwide potential," ILO, 2020, https://www.ilo.org/wcmsp5/groups/public/---ed protect/---protrav/--travail/documents/briefingnote/wcms 743447.pdf

5 "Report on the future of work," IBA, 2019, https://www.carey.cl/download/filebase/noticias/IBAReport-on-the-Future-of-Work-2019.pdf.

6 Lubica Bajzikova, Helena Sajgalikova, Emil Wojcak, and Michaela Polakova. "How Far is Contract and Employee Telework Implemented in SMEs and Large Enterprises? (Case of Slovakia)." Procedia - Social and Behavioral Sciences 235 (2016), 420-426. doi: 10.1016/j.sbspro.2016.11.052

7 Ravi S. Gajendran, and David A. Harrison. "The good, the bad, and the unknown about telecommuting: Meta-analysis of psychological mediators and individual consequences." Journal of Applied Psychology 92, no. 6 (2007), 1524-1541. doi:10.1037/0021-9010.92.6.1524.

8 O. Kosenko, Legal regulation of remote employment of workers in Ukraine. (Kharkiv: Law, 2015). 
the cost of renting premises, cleaning, meals, etc. In addition, given that the modern labor market of the European Union no longer satisfies the demand for workers, including highly skilled, telework is a great way to attract foreign workers, that will reduce the cost of moving, living, and so on. ${ }^{9}$ The use of information technology today is an integral part of our life. With their help, an increasing number of people are able to work from remote places, that is, outside the premises of their employer, through the use of computer networks and telecommunication devices.

The research of theoretical and practical problems associated with the use of telecommuting in the science of labor law became relevant in the late twentieth century. Scientific achievements in this field are reflected in the works of scientists such as L. Bajzikova, H. Sajgalikovab, E. Wojcakc and M. Polakova ${ }^{10}$, M. Dei and H. Dei ${ }^{11}$, R. Gajendran and D. Harrison ${ }^{12}$, S. Silchenko and D. Serbina ${ }^{13}$, V. Kosenko ${ }^{14}$, and others. For example, J. Messenger and L. Gschwind ${ }^{15}$ payed attention that new information and communication technology', such as smartphones and tablet computers, have revolutionised work and life in the 21st century. Crucial to this development is the detachment of work from traditional office spaces. Today's office work is often supported by Internet connections, and thus work can be done from anywhere at any time. In addition, M. Grzegorczyk, M. Mariniello, L. Nurski and T. Schraepen ${ }^{16}$ mentioned that a great deal of attention has been focused on the concept of telework during the COVID19 pandemic.

The pandemic crisis has shown that: 1) More flexible working conditions are possible without necessarily affecting workers' productivity or increasing costs. There is thus a potential new supply of opportunities from the employers' side.; 2) More flexible working conditions are desired by workers, insofar as embracing them does not put remote workers at a disadvantage or affect their well-being. There is thus a potential new demand for flexible working arrangements. ${ }^{17}$ Telework facilitates flexibility and a strong work-family balance while reducing the environmental impacts of mobility. ${ }^{18}$

M. Inshin ${ }^{19}$ researching the role of telework in a market economy, noted that the development of remote employment is a positive indicator for a market economy and

\footnotetext{
9 T. Kortukova, "Legal Aspects of Employment of Highly Qualified Migrant Workers in the European Union." Scientific Bulletin of the National Academy of Internal Affairs 118, no. 1 (2021), 112-117. doi: 10.33270/01211181.112.

10 Bajzikova, Sajgalikova, Wojcak, and Polakova, "How Far is Contract," 420-26.

11 Dei, and Dei, "Labor security in conditions," 299-304.

12 Gajendran, and Harrison, "The good, the bad, and the unknown," 1524-1541.

13 Silchenko, and Serbina, "Remote working: current state," 93-99.

14 Kosenko, "Legal regulation of remote employment," 2015.

${ }^{15}$ Jon C. Messenger, and Lutz Gschwind. "Three generations of Telework: New ICTs and the (R)evolution from Home Office to Virtual Office." New Technology, Work and Employment 31, no. 3 (2016), 195-208. doi: 10.1111/ntwe.12073.

${ }^{16}$ M. Grzegorczyk, M. Mariniello, L. Nurski, and T. Schraepen, "Blending the physical and virtual: a hybrid model for the future of work." Policy Contribution 14, (2021), 1-22.

${ }^{17}$ Grzegorczyk, Mariniello, Nurski, and Schraepen, "Blending the physical and virtual," 1-22.

${ }^{18}$ Angel Belzunegui-Eraso, and Amaya Erro-Garcés. "Teleworking in the Context of the Covid-19 Crisis." Sustainability 12, no. 9 (2020), 3662. doi: 10.3390/su12093662.

19 Inshin, M. "Remote employment of workers in a market economy." Law Forum 3 (2014), 466-469.
} 
provides an increase in living standards, the creation of new forms of employment, promotes economic stability, etc. At the same time, taking into account the results of the analysis of recent research and publications, it becomes clear that the topic is relevant and requires detailed research. In addition, the current challenges facing society in the context of the spread of the COVID-19 pandemic require a comprehensive study of the nature and importance of telework as a special form of employment.

\section{Method}

The methodology used in the article is determined by the objectives of the study. In particular, the methods of scientific research were used to learn about the objective reality of some aspects of remote work in Ukraine and the EU. It should be noted that the formulation of conceptual provisions on the features of remote work in Ukraine and the EU was carried out considering the methodological foundations of the current stage of development of science. The research was conducted on the basis of a dialectical materialist methodology that reflects the relationship between theory and practice, according to which research methods were used. The methodological basis of the research was formed by the dialectical approach to understanding the peculiarities of remote work in Ukraine and the EU. At the same time, the scientific tools of the work were based on the principles of objectivity and pluralism of knowledge of remote work in Ukraine and the EU. ${ }^{20}$ In addition, the methodological basis of the article were methods that allow to solve problems and achieve research goals. In solving problems, the author relied on modern methods of cognition, defined and developed by modern science and tested in practice.

In particular, the methodological basis of the study are general and special methods and techniques of cognition. For example, during the writing of the article, such general scientific methods as analysis, synthesis, comparison, analogy, deduction, induction, abstraction, were used as methods to achieve new knowledge. In our opinion, this group of methods represents the most suitable ways to study cognition, as they allow to consider it from different aspects, achieve satisfactory results and build a reliable basis for future developments. Thus, the inductive method allowed to generalize and formulate the approaches of scientists to the peculiarities of remote work in Ukraine and the EU. The deductive method allowed to consistently argue the position of the author. Other formal logical methods, such as analysis, synthesis, generalization, abstraction, were used to draw conclusions. In the process of working on the article, methods of transition from theoretical and legal abstraction to branch concretization, method of normative modeling, method of legal forecasting were also involved. Consideration of the subject of research was carried out within the framework of an integrated approach, which involves a combination of such special methods as structural-functional, comparative-legal and formal-legal analysis.

20 Oleg M. Yaroshenko, and Kirill L. Tomashevski. "The influence of Covid-19 on labor and social relations: Rules of memory of Belarus and Ukraine." Journal of the National Academy of Legal Sciences of Ukraine 28, no. 2 (2021), 211-221. doi: 10.37635/jnalsu.28(2).2021.211-221. 
For example, the formal-legal method helped to understand the essence of remote work in Ukraine and the EU. The structural-functional method helped in the process of identifying specific features inherent in remote work in Ukraine and the EU. In the course of comparing the legislation of Ukraine and the legislation of the European Union, the comparative legal method was used. The use of the above methods made it possible to explore as deeply as possible the issues considered in the study. In addition, a study using the above methods and approaches found that the issue is not only theoretical but also of great practical importance.

The normative basis of the work was the Constitution of Ukraine, the Labor Code of Ukraine, other laws and regulations, as well as the EU acquis. In the course of the work the materials of law-making, law-enforcement and interpretive practice were studied. In particular, the empirical basis of the study was case law on research issues, as well as materials of scientific conferences and seminars, reports, discussions, reflecting the views of their participants on various aspects of problems in the legal regulation of telework in Ukraine and the EU. ${ }^{21}$

\section{Results}

The definition of "remote work" was first used in 1972 in the United States by the founder of this concept J. Nilles, after which the development of virtual firms began, which used a non-standard form of business organization. Among those who actively apply similar practices today are American Express, Adobe, Airbus Industries, Siemens, Microsoft, Google, Corel, IBM, DELL, eBay, Hewlett-Packard and many other well-known and less popular companies. ${ }^{22}$ It should be noted that working outside the office has a number of positive and negative aspects. The first include: the employee's lack of time and money to travel to the place of work, the performance of the labor function at a convenient time for them (including being on sick leave, on parental leave, on annual leave), selfregulation of working time, independent choice of tactics for fulfilling the tasks of the employer. In addition, this type of employment is convenient for those categories of citizens who find it difficult to find work: for people with disabilities, pensioners, women with many children. For the employer - saving money on job creation, overhead costs, optimization of human resources.

The negative ones include the complexity of $\mathrm{HR}$ administration, certification, transfer and dismissal of a remotely working employee, the presence of risks of non-performance of work; lack of a mechanism for protecting commercial secrets, the possibility of intercepting or losing data transmitted over the Internet; the impossibility of controlling the working time and rest time of the employee, their observance of labor protection standards, sanitary and hygienic standards, etc., the uncertainty of the status of a remote worker and, as a result, his legal and social insecurity. All or almost all of the negative

21 K.L. Tomashevski, and O.N. Yaroshenko, "Problems of Labour Legislation Codification in Belarus and Ukraine: History, Current Situation and Prospects." Journal Transition Studies Review 27, no. 2 (2020), 4149. https://doi.org/10.14665/1614-4007-27-2-004

22 A. Sardaryan, "How to manage personnel in virtual companies?" Human Resources Management, 3 (2010), 38-41. 
aspects arise from the lack of legal regulation of social and labor activities. ${ }^{23}$ To the preconditions for the formation of remote employment in Ukraine, according to $\mathrm{M}$. Motsar ${ }^{24}$, include the following factors: labor market instability, pension fund deficit, declining employment growth and labor force in the manufacturing sector; rising hidden unemployment; accumulation of overstaffing; manifestations of discrimination on the basis of age, regional location, lack of official work experience; difficulty in finding employment for people with young children; unforeseen waves of reductions, one in five Ukrainians is looking for work for more than a year against the background of high rates of development of information and communication technologies.

In Ukraine, until 2020 the procedure and conditions for the use of remote operation was not clearly regulated at the legislative level. Today, in accordance with Part 10 of Art. 60 of the Labor Code, remote (home) work is a form of work organization in which work is performed by an employee at their place of residence or elsewhere at their choice, with the help of information and communication technologies, but outside the employer's premises. After analyzing the above definition, it should be noted that telework is identified with homework, and the Ukrainian legislator still does not distinguish between the two concepts, although it would be logical to do so, as they are different in their legal nature. Among the features of telecommuting is that it cannot limit the scope of labor rights of employees. That is, employees have the right to rest (weekends, holidays), lunch break and so on. In the case of telework, employees distribute working time at their own discretion, they are not subject to the rules of internal labor regulations, unless otherwise provided in the employment contract.

In addition, the conclusion of an employment contract is mandatory for telework. However, there are exceptions to this imperative rule. Thus, if there is a threat of an epidemic, pandemic, threat of a military, man-made, natural or other nature, then it is enough to issue an order for such form of work. But the total duration of working hours may not exceed the norms established in Articles 50 and 51 of the Labor Code of Ukraine. It should also be noted that the introduction of remote work is a change to significant working conditions, as in accordance with Article 32 of the Labor Code of Ukraine and paragraph 3 of paragraph 31 of the Plenum of the Supreme Court of Ukraine "On the practice of labor disputes" No 9 to 06.11 .1992 belongs to the mode of operation.

Therefore, if the remote mode of operation is established at the initiative of the employer, it must notify the employee no later than 2 months. If the employee applies to the employer to establish such a mode of work, the specified period does not apply. ${ }^{25}$ Also, in Ukraine, remote employment is enshrined in the Law of Ukraine "On Scientific and Scientific Technical Activity" of November 26, 2015. In particular, Article 6 states that for researchers and specialists of scientific institutions and higher education institutions

23 "Remote work in Ukraine: issues of legal regulation," Y. Svechkareva, 2018, https://jurnal.org/articles/2013/uri9.html

24 M. Motsar, International aspects and prerequisites for the formation of distance employment in Ukraine. (SWWorld: Modern Problems and Ways to Solve Them in Science, Transport, Manufacturing, and Education, 2012).

25 S. Vyshnovetska, and A. Artemenko, "Remote operating mode as one of the essential working conditions." Law and Society 5 (2020), 49-54. 
may be introduced remote work. The possibility of introducing flexible working hours and remote working hours in a scientific institution (higher education institution) is determined in the collective agreement or by the decision of the head of the scientific institution (higher education institution) in agreement with the elected body of the primary trade union organization. The specific list of professions and positions of a scientific institution (higher education institution), where flexible working hours and remote work mode can be applied, is approved by the scientific (scientific, scientifictechnical, technical) council of the scientific institution (higher education institution).

The procedure and conditions for the application of flexible working hours and remote working hours are determined in the rules of internal labor regulations of a scientific institution (higher education institution). In response to the pandemic, Ukraine adopted Law No 540-IX of March 30, 2020. Thus, in accordance with paragraph 2.1 of this law, it is established that for the period of quarantine or restrictive measures related to the spread of coronavirus disease (COVID-19), the employer may instruct the employee, including civil servant, local government employee, to perform during for a certain period of time, the work specified in the employment contract, at home, as well as to provide the employee, including a civil servant, an employee of a local government, with his consent, leave. In the near future, the issue of remote work in Ukraine will increasingly prove its relevance as something more effective and attractive than traditional forms of employment.

That is why, it is necessary to systematize this area. At the moment, Ukrainian legislation only regulates the basic conditions for remote work and some legal aspects need to be improved. It should be mentioned, that for more efficient labor productivity and labor discipline of remote work, it is necessary to revise and legislatively regulate the key principles of compliance by employees with labor discipline and provide the employee with proper working conditions. In addition, a legal regime needs to be developed to ensure compliance with internal security requirements and measures. Also, it is important to strengthen the contractual framework for the regulation of remote work through the introduction of an approximate form of employment contract with a teleworker, which can be taken as a basis when concluding the relevant employment contracts. Thus, effective legal regulation of distance employment can become a tool to stimulate economic activity of the population.

\section{Framework Agreement in the European Experience}

Regarding the situation with teleworking in the European Union, it should be noted that before the pandemic, only a small proportion of workers periodically worked remotely. In the European Union, the prevalence of regular or occasional teleworking ranged from 30 percent or more in Denmark, the Netherlands, and Sweden and to 10 percent or less in the Czech Republic, Greece, Italy and Poland. ${ }^{26}$ As a result of government restrictive measures, nearly four out of every ten employees in Europe have switched to

26 Eurofound and ILO, Working Anytime, Anywhere: The Effects on the World of Work. (Luxembourg and Geneva: Publications Office of the European Union and ILO, 2017). 
telecommuting. ${ }^{27}$ The most significant expansion in telecommuting has been in the countries hit hardest by the coronavirus and where teleworking was well developed prior to the pandemic. In Finland, about 60 percent of workers have switched to telecommuting. In Luxembourg, the Netherlands, Belgium and Denmark, more than 50 percent of workers worked remotely, while in Ireland, Austria, Italy and Sweden, about 40 percent.

In these countries, fewer workers have reduced working hours. This jump in numbers shows that with the correct use of the appropriate technology and mechanisms (for example, communication means) and changes in the organization of the work process, many more types of work can be performed remotely than previously thought. ${ }^{28}$ In the EU, the legal basis for remote employment was developed and adopted in 2002, when the Framework Agreement on Telework was adopted.

The Framework Agreement defines the types of telework that are carried out on the basis of an employment contract, emphasizing that teleworkers (remote workers) enjoy the same rights as ordinary workers. A unique feature of this Framework Agreement is that it has not been implemented on the basis of a European Directive. Instead, this agreement was to be implemented "autonomously", "in accordance with procedures and practices specific to management and labor in each member state". The implementation of this Framework Agreement took place in the following ways: through the conclusion of domestic agreements at the national and intersectoral levels; through the development of measures such as common guidelines, codes of conduct and recommendations for teleworking; through the adoption of special legislation.

For example, in Finland, Ireland, Latvia, the Netherlands, Sweden, its provisions were included in acts of a recommendatory nature (in particular, in codes of conduct). In Austria, Belgium, Denmark, Germany, Greece, France, Italy, Luxembourg, Spain, they are reflected in collective agreements mainly at the national and intersectoral levels. In the Czech Republic, Hungary, Poland, Portugal, Slovakia and Slovenia, implementation took place through amendments and additions to the current labor legislation. ${ }^{29}$ The purpose of the agreement under consideration is to solve such problematic issues as assessing the current state of telework in the EU, studying the issues of employment and working conditions for workers involved in telework, as well as the formation of a common policy in this area not only from the direct participants in social partnership, but also from governments. member states. The concept of telework is given in Article 2 of the European Framework Agreement on Telework 2002, where it is determined that "telework is one of the forms of organizing and / or performing work, using information technology, in the context of an employment contract / relationship, where work, which can also be performed at the employer's premises, carried out outside these premises on a regular basis".

27 Eurofound, Living, working and COVID-19: First findings. (Dublin: Eurofound, 2020).

28 Eurofound, "Living, working and COVID-19," 2020.

29 Eurofound, Telework in the European Union. (Dublin: Eurofound, 2010). https://www.eurofound.europa.eu/publications/report/2010/telework-in-the-european-union 
After analyzing this definition, we can conclude that the concept of telework is much narrower than the concept of telework (remote) work and, therefore, is its kind. The definition of telework given in the framework agreement is quite successful and most of the member states of the European Union have used it in one form or another in their regulations. The EU Framework Agreement sets out a number of important issues and features that make it possible to effectively protect the rights of workers. In particular, the key points in relation to the rights granted to teleworkers, which the countries parties to the agreement have undertaken to incorporate into their national laws and collective agreements, are: the protection of information; the voluntary nature of telecommuting; equipment; organization of working time; privacy. Typically, the employer is responsible for providing, installing and maintaining the equipment required for telecommuting when the employee is not using their equipment. If the work is performed on a regular basis, the employer usually compensates or covers the costs directly caused by the work, in particular those related to communication. The employer provides the employee with appropriate technical support. ${ }^{30}$

Article 6 of the Framework Agreement refers to the need to protect the privacy of teleworkers. As stated in this article, the installation of surveillance equipment for teleworkers is only permitted in accordance with the provisions of EU Directive 90/270/EEC on minimum labor protection requirements for devices equipped with video monitors. The adoption of this regulation is associated with increased motivation of employers to control teleworkers using electronic devices. In the future, the approach of the structures of the European Union to remote work was somewhat modified. In 2015, the European Fund for the Improvement of Working and Living Conditions released a study on the so-called new forms of employment. Among them, ICT-based mobile work is mentioned. ICT-based mobile work is an employment relationship performed at least partially but regularly outside the employer's "main office" or specially adapted home space, using ICTs to connect to the company's general computer networks. The Eurofound distinguishes this form of labor relations from "traditional teleworking" 31 , pointing out that the latter is characterized by being tied to a specific place of work, remote from the employer (for example, to the employee's home), while mobile work based on ICT does not imply any fixation of the workplace. This distinction is somewhat similar to the distinction between telecommuting and home-based work.

\section{Key Problems of Remote Work}

At the same time, one of the key problems of distance employment that European countries face is the isolation of workers from the collective. While at the initial stage such isolation is perceived by many as a blessing, then later it leads to the emergence of

30 Oleg M. Yaroshenko, Natalya M. Vapnyarchuk, Yulia M. Burnyagina, Nina V. Kozachok-Trush, and Leonid V. Mohilevskyi. "Professional Development of Employees as the Way to Innovative Country Integration." Journal of Advanced Research in Law and Economics 11, no. 2 (2020), 683. doi:10.14505/arle.v11.2(48).39.

31 Eurofound, "Telework in the European Union," 2010. https://www.eurofound.europa.eu/ publications/report/2010/telework-in-the-european-union 
psychological and economic difficulties. ${ }^{32}$ In general, in Belgium, Czechia, Spain, France, Greece, Hungary, Croatia, Italy, Lithuania, Luxembourg, Malta, the Netherlands, Poland, Portugal, Romania, Slovenia and Slovakia, there are statutory definitions of telework or related national categories, for example "remote work" in Bulgaria, "distance work" in Spain (later replaced by telework), "alternative workplace" in Croatia and "locationindependent" work in the Netherlands. In most of these countries, national statutory definitions resemble the wording used in the EU Framework Agreement or follow a similar approach. ${ }^{33}$ In the context of the spread of the new coronavirus infection in many countries of the world, the process of legislative consolidation of various aspects of teleworking, working conditions, as well as the rights and obligations of employers and workers has begun.

For example, the working conditions regulation in the Netherlands covers paid work performed by an employee at his place of residence or other place of his choice outside the employer's production facility. At the same time, the obligation of the employer to check the working conditions of the employee and to ensure compliance with the legal obligations established by the decree is provided. In Poland, the Labor Code, including the concept of "teleworking", emphasizes that the place of work must be located outside the employer's production facility and that work must be done electronically; in Austria, "teleworking" is within the scope of working hours legislation and is not subject to separate regulation. ${ }^{34}$ Despite the rapid development in the field of information and communication technologies, France is not as developed in the field of teleworking as other similarly developed European countries. Therefore, a law supporting teleworking was adopted in 2012. Despite this law, France faces many problems with this type of work.

However, teleworkers are still not as well regarded as traditional workers. French labour law prohibits teleworkers from having employees themselves, with the exception of the help of their spouse, dependent children or support staff. The employee also has the right to "refuse to take the place of a distance worker and that is not a reason for terminating the employment contract". ${ }^{35}$ At the same time, Germany provides no legal right to work at home, with some opinions suggesting that company-level agreements are better suited to create appropriate rules. It seems, however, that some modernising of national health and safety regulations would be necessary in order to ensure that more flexible forms of work are covered (beyond clearly defined teleworking) and that the specific

32 "Does workplace isolation matter? Examining the impact of workplace isolation on telecommuter work engagement," S.A. Arora, 2012, https://www.semanticscholar.org/paper/Does-Workplace-IsolationMatter-Examining-the-of-on-Arora/9d15ce04be1b9b672482a9e20dce5b4007232938

33 P. Sanz de Miguel, M. Caprile, and J. Arasanz, Regulating telework in a post-COVID-19 Europe. (EUOSHA: European Agency for Safety and Health at Work, 2021).

34 "Remote working in the COVID-19 pandemic: a guide for employers Geneva," ILO, 2020, https://www.ilo.org/wcmsp5/groups/public/---ed dialogue/--act emp/documents/publication/wcms 745024.pdf

35 Pavel Sládek, and Tomáš Sigmund. "Legal Issues of Teleworking." SHS Web of Conferences 90 (2021), 01020. doi:10.1051/shsconf/20219001020. 
requirements of mobile working are considered. Clarity about time recording would remove some employers' uncertainties about this way of working. ${ }^{36}$

Working remotely creates many problems for employees in Ukraine, especially for women. First of all, steps need to be taken to develop conditions that reduce and redistribute unpaid domestic work through the egalitarian practice of work-life balance in the workplace. However, in general, low-skilled workers suffer the most from containment measures, as teleworking is rare in Ukraine, and Ukraine has the highest share of low-skilled workers in total employment (19.1 percent) compared to other Eastern Partnership countries. This means that restrictions can have a regressive effect on income distribution. In addition, because informal workers tend to receive low wages and usually have very low savings, they are less able to compensate for income losses caused by withdrawal policies. In many cases, their living conditions (especially the living conditions of migrant workers) can complicate significant physical distancing, increasing the risk of infection. At the same time, the informal workforce often plays a major role in some important sectors, such as waste disposal, agriculture and freight. Therefore, quarantine-related changes have been made to the Labor Code of Ukraine, which regulate the new reality of remote work, flexible scheduling and wages. ${ }^{37}$

\section{Conclusion}

In the period of globalization and the development of information and communication systems, new non-standard forms of employment appear, designed to meet the needs of modern society. One of these new flexible forms of employment is teleworking, which has already found legislative support in most countries of the world. The rapid development of informatization and means of communication (communications), which significantly simplified the possibility of remote communication between the employer and employees in various forms, led to the need to change labor legislation in terms of the use of remote work. Moreover, due to the COVID-2019 pandemic, employers had to provide their employees with the opportunity to work remotely for an extended period of time. On the one hand, not all employers and employees had enough organizational and technical capabilities to switch to remote work, and on the other hand, forced measures proved the effectiveness of interaction at a distance. Remote work is seen as a positive process, although it faces some difficulties in implementation, it is increasingly used by companies.

However, in the science of labor law there is no concept of remote work. All this requires increased attention of both scholars and legislators, necessitates proper legal regulation, which would be based on the doctrinal developments of scientists. In particular, in the

\footnotetext{
${ }^{36}$ Manuela S. Lodovici, Elena Ferrari, Emma Paladino, Flavia Pesce, Pietro Frecassetti, Eliat Aram, Kari P. Hadjivassiliou, Kerstin Junge, Anna S. Hahne, and Dave Drabble. The Impact of Teleworking and Digital Work on Workers and Society: Special Focus on Surveillance and Monitoring, as Well as on Mental Health of Workers. (Luxembourg: Policy Department for Economic, Scientific and Quality of Life Policies, 2021).

37 "COVID-19 in Ukraine: Impact on Households and Businesses," UN Women, 2020, https://www.ua.undp.org/content/dam/ukraine/docs/DG/covid\%20impact/COVID19\%20in\%20Ukraine I mpact\%20on\%20Households\%20and\%20Businesses.pdf
} 
European Union, the key points in relation to the rights granted to teleworkers, which the contracting states have undertaken to incorporate into their national laws and collective agreements, are: data protection; the voluntary nature of telecommuting; equipment; organization of working time; privacy. Ukrainian legislation is actively developing towards the implementation of the generally recognized principles of international law and the law of the European Union. At the same time, in order to overcome the existing problems, it is necessary to improve the legislation by distinguishing between remote and homework, to specify the procedure and conditions for implementing remote work, to determine the legal status of the employee and employer, and so on.

For more effective labor productivity, labor discipline, compliance with labor guarantees when working remotely, it is necessary to revise and legislatively regulate the key principles of employees' compliance with labor discipline, providing the employee with adequate working conditions, supporting the employer in finding new opportunities to provide employees with work, improving the technical aspects of ensuring the relationship between business and government, responsibility for the results and the labor process. To optimize the legal regulation of remote employment in Ukraine in the Labor Code of Ukraine should include the procedure for concluding an employment contract, the provision according to which the employer is obliged to ensure compliance with labor protection requirements and sanitary and hygienic standards. In addition, it is necessary to develop a state policy in the field of employment aimed at stimulating the development of remote employment, as well as to create special institutions that should provide and coordinate remote employment.

\section{References}

Andrushkiv, B. "Distance work and freelance activity: features and differences." Scientific Information Bulletin 11, (2015), 233-237.

Arora, S.A. "Does workplace isolation matter? Examining the impact of workplace isolation on telecommuter work engagement." (2012), https://www.semanticscholar.org/paper/DoesWorkplace-Isolation-Matter-Examining-the-of-onArora/9d15ce04be1b9b672482a9e20dce5b4007232938

Bajzikova, Lubica, Helena Sajgalikova, Emil Wojcak, and Michaela Polakova. "How Far is Contract and Employee Telework Implemented in SMEs and Large Enterprises? (Case of Slovakia)." Procedia - Social and Behavioral Sciences 235 (2016), 420-426. doi: 10.1016/j.sbspro.2016.11.052

Belzunegui-Eraso, Angel, and Amaya Erro-Garcés. "Teleworking in the Context of the Covid-19 Crisis." Sustainability 12, no. 9 (2020), 3662. doi:10.3390/su12093662.

Dei, M., and Dei, H. "Labor security in conditions of digital globalization." Fundamental and Applied Researches in Practice of Leading Scientific Schools, 26 no. 2 (2018)., 299-304.

Eurofound and ILO. Working Anytime, Anywhere: The Effects on the World of Work. Luxembourg and Geneva: Publications Office of the European Union and ILO, 2017.

Eurofound. Living, working and COVID-19: First findings. Dublin: Eurofound, 2020. 
Eurofound. Telework in the European Union. Dublin: Eurofound, 2010. https://www.eurofound.europa.eu/publications/report/2010/telework-in-the-europeanunion

Gajendran, Ravi S., and David A. Harrison. "The good, the bad, and the unknown about telecommuting: Meta-analysis of psychological mediators and individual consequences." Journal of Applied Psychology 92, no. 6 (2007), 1524-1541. doi:10.1037/00219010.92.6.1524.

Grzegorczyk, M., Mariniello, M., Nurski, L., and Schraepen, T. "Blending the physical and virtual: a hybrid model for the future of work." Policy Contribution 14, (2021), 1-22.

IBA.

"Report on the future of work."

(2019), https://www.carey.cl/download/filebase/noticias/IBA-Report-on-the-Future-of-Work2019.pdf.

ILO. "Remote working in the COVID-19 pandemic: a guide for employers Geneva." (2020), https://www.ilo.org/wcmsp5/groups/public/---ed dialogue/--act emp/documents/publication/wcms 745024.pdf

ILO. "Working from home: estimating the worldwide potential." (2020), https://www.ilo.org/wcmsp5/groups/public/---ed protect/---protrav/--travail/documents/briefingnote/wcms 743447.pdf

Inshin, M. "Remote employment of workers in a market economy." Law Forum 3 (2014), 466469.

Kortukova, T. "Legal Aspects of Employment of Highly Qualified Migrant Workers in the European Union." Scientific Bulletin of the National Academy of Internal Affairs 118, no. 1 (2021), 112-117. doi:10.33270/01211181.112.

Kosenko, O. Legal regulation of remote employment of workers in Ukraine. Kharkiv: Law, 2015.

Lodovici, Manuela S., Elena Ferrari, Emma Paladino, Flavia Pesce, Pietro Frecassetti, Eliat Aram, Kari P. Hadjivassiliou, Kerstin Junge, Anna S. Hahne, and Dave Drabble. The Impact of Teleworking and Digital Work on Workers and Society: Special Focus on Surveillance and Monitoring, as Well as on Mental Health of Workers. Luxembourg: Policy Department for Economic, Scientific and Quality of Life Policies, 2021.

Messenger, Jon C., and Lutz Gschwind. "Three generations of Telework: New ICTs and the (R)evolution from Home Office to Virtual Office." New Technology, Work and Employment 31, no. 3 (2016), 195-208. doi:10.1111/ntwe.12073.

Motsar, M. International aspects and prerequisites for the formation of distance employment in Ukraine. SWWorld: Modern Problems and Ways to Solve Them in Science, Transport, Manufacturing, and Education, 2012.

Sanz de Miguel, P., Caprile, M., and Arasanz, J. Regulating telework in a post-COVID-19 Europe. EU-OSHA: European Agency for Safety and Health at Work, 2021.

Sardaryan, A. "How to manage personnel in virtual companies?" Human Resources Management, 3 (2010), 38-41.

Silchenko, Serhii, and Diana Serbina. "Remote working: current state and prospects of legal regulation." Entrepreneurship, Economy and Law, no. 1 (2021), 93-99. doi:10.32849/26635313/2021.1.16. 
Sládek, Pavel, and Tomáš Sigmund. "Legal Issues of Teleworking." SHS Web of Conferences 90 (2021), 01020. doi:10.1051/shsconf/20219001020.

Svechkareva, Y. Remote work in Ukraine: issues of legal regulation, 2018. https://jurnal.org/articles/2013/uri9.html

Tomashevski, K.L., and Yaroshenko, O.N. "Problems of Labour Legislation Codification in Belarus and Ukraine: History, Current Situation and Prospects." Journal Transition Studies Review 27, no. 2 (2020), 41-49. https://doi.org/10.14665/1614-4007-27-2-004

UN Women. "COVID-19 in Ukraine: Impact on Households and Businesses." (2020), https://www.ua.undp.org/content/dam/ukraine/docs/DG/covid\%20impact/COVID19\%20i n\%20Ukraine_Impact\%20on\%20Households\%20and\%20Businesses.pdf

Vyshnovetska, S., and Artemenko, A. "Remote operating mode as one of the essential working conditions." Law and Society 5 (2020), 49-54.

Yaroshenko, Oleg M., and Kirill L. Tomashevski. "The influence of COVID-19 on labor and social relations: Rules of memory of Belarus and Ukraine." Journal of the National Academy of Legal Sciences of Ukraine 28, no. 2 (2021), 211-221. doi:10.37635/jnalsu.28(2).2021.211221.

Yaroshenko, Oleg M., Natalya M. Vapnyarchuk, Yulia M. Burnyagina, Nina V. Kozachok-Trush, and Leonid V. Mohilevskyi. "Professional Development of Employees as the Way to Innovative Country Integration." Journal of Advanced Research in Law and Economics 11, no. 2 (2020), 683. doi:10.14505/arle.v11.2(48).39.

Conflict of Interest Statement: The author(s) declares that the research was conducted in the absence of any commercial or financial relationship that could be construed as a potential conflict of interest.

Copyright: (C) HALREV. This is an open access article distributed under the terms of the Creative Commons Attribution 4.0 International License (CC-BY 4.0), which permits unrestricted use, distribution, and reproduction in any medium, provided the original author and source are credited.

Hasanuddin Law Review (Hasanuddin Law Rev. - HALREV) is an open access and peer-reviewed journal published by Faculty of Law, Hasanuddin University, Indonesia. 